\title{
PÓŹNOŚREDNIOWIECZNE NACZYNIA Z MIĘDZYRZECZA. PRZYCZYNEK DO STUDIÓW NAD POCHODZENIEM I UŻYTKOWANIEM WYROBÓW SZKLANYCH
}

\author{
CONTRIBUTION TO STUDIES ON THE USE AND ORIGIN \\ OF LATE MEDIEVAL GLASS VESSELS. \\ VESSELS FROM MIĘDZYRZECZ
}

\begin{abstract}
In the late medieval settlement layers of the gord in Międzyrzecz, a small collection of glass vessels was excavated. Several forms of tableware were reconstructed and research was conducted into the chemical composition of the glass. The examined piece of a vessel and the glass is potassium glass which comes in two varieties: calcium-potassium-magnesium-silica $\left(\mathrm{CaO}-\mathrm{K}_{2} \mathrm{O}-\mathrm{MgO}-\mathrm{SiO}_{2}\right)$ and calcium-potassium-magnesium-aluminium-silica $\left(\mathrm{CaO}-\mathrm{K}_{2} \mathrm{O}-\mathrm{MgO}-\mathrm{Al}_{2} \mathrm{O}_{3}-\mathrm{SiO}_{2}\right)$. The forms of the vessels and the chemical composition of the examined glass indicate the basic goods manufactured in Central Europe.
\end{abstract}

Keywords: late Middle Ages, Międzyrzecz, gord, glass vessels, potassium glass.

\section{WPROWADZENIE}

Rozwój badań nad dziejami średniowiecznego i nowożytnego szklarstwa opiera się w dużej mierze na napływie nowych źródeł archeologicznych. Badania wykopaliskowe prowadzone na obszarach zabytkowych centrów miast, w zamkach i klasztorach dostarczyły licznych materiałów archeologicznych. Studia podjęte nad nimi pozwoliły określić szeroką problematykę badawczą - od badań nad hutnictwem szkła, technologią i techniką - wspomaganych przez szeroko pojęte badania fizykochemiczne, po rozległe studia porównawcze i związane z tym problemy nazewnictwa, typologii, identyfikacji i pochodzenia wyrobów miejscowych, importo-

* ORCID: 0000-0001-5515-892x; Instytut Archeologii i Etnologii PAN - Ośrodek Studiów Pradziejowych i Średniowiecznych, ul. Rubież 46, 61-612 Poznań, e-mail: sawicka@man.poznan.pl. 
wanych czy dalej - wkraczających w zakres wymiany handlowej i sferę statusu społecznego użytkowników.

Poniżej przedstawiono materiały pochodzące z późnośredniowiecznych poziomów osadniczych grodu w Międzyrzeczu. Odkryty tam zbiór naczyń szklanych pozyskano podczas prac wykopaliskowych prowadzonych w ramach badań milenijnych w latach 1953-1961 na stanowisku 1 (zamek), początkowo przez Muzeum Archeologiczne w Poznaniu, a od roku 1958 przez Pracownię Historii Kultury Materialnej Ziemi Lubuskiej IHKM PAN - pod kierownictwem Stanisława Kurnatowskiego. Badania prowadzono na dziedzińcu zamku wzniesionego za panowania Kazimierza Wielkiego, w miejscu wcześniejszego grodu. Założono wówczas szereg wykopów badawczych na majdanie grodu i na terenie przyległej osady. Liczny ruchomy materiał zabytkowy zawierał przedmioty ze szkła (również znaleziska łączone z jego produkcją - Olczak 1960, 1995; Sawicka 2015). Odkryto duży zbiór ułamków naczyń i nielicznych wspomnianych tu jedynie szyb, pochodzących z warstw z XIII i z XIV w., i te materiały są przedmiotem poniższego opracowania.

Miasto lokacyjne w Międzyrzeczu, założone prawdopodobnie na prawie magdeburskim, istnieje co najmniej od połowy XIII wieku' ${ }^{1}$ W XII i XIII w. - w okresie szybkiego wzrostu zaludnienia, dogodne położenie komunikacyjne Międzyrzecza sprzyjało wczesnemu powstaniu osady targowej. W 3. ćwierci XIII w. w ośrodku międzyrzeckim znajdowały się trzy centralne miejsca zabudowy: gród na wyspie, osada targowa powstała w 2. połowie XII w. i pierwsze miasto lokacyjne założone około połowy XIII w. na północnym brzegu Obry. Spalony w roku 1269 gród odbudowano, a świadectwa archeologiczne wskazują na jego intensywne użytkowanie jako siedziby kasztelanii (Kurnatowski 2015, s. 33-35). Znaleziska archeologiczne pochodzące $\mathrm{z}$ tego okresu (także $\mathrm{z}$ późniejszego, budowy zamku) poświadczają przebywanie $\mathrm{w}$ grodzie załogi wojskowej. Obok licznych militariów odnotowano wyraźne ślady obecności, zwłaszcza w fazach młodszych, przedstawicieli ówczesnej elity władzy. Świadczą o tym między innymi luksusowe przedmioty związane z wyposażeniem jeździeckim, misy żelazne, stilusy, ozdobne obuwie, części stroju, figury i kamienie do gier, nieliczne wyroby złotnicze czy ozdobne okucie księgi z kawałkiem oprawy skórzanej zdobionej wizerunkiem orła piastowskiego (Kurnatowski, Nalepa 1961, s. 131 i n.; Banach, Kurnatowski, Urbańska -Łosińska, Zamelska-Monczak 2015, s. 217-264). Oczywistym uzupełnieniem tych inwentarzy są naczynia szklane. Źródła pisane nie podają ściślejszych dat budowy murowanego zamku, lokowanego na grodzie i kończącego długi okres jego egzystencji. Wiadomo tylko, iż według kroniki Janka z Czarnkowa, główny etap budo-

${ }^{1}$ Wiadomości o w pełni już miejskim charakterze Międzyrzecza zawiera dokument z roku 1259. Najwcześniejsza wzmianka źródeł pisanych o istnieniu kasztelanii międzyrzeckiej pochodzi z $1232 \mathrm{r}$. (Kurnatowski, Nalepa 1961, s. 18 i n.). 


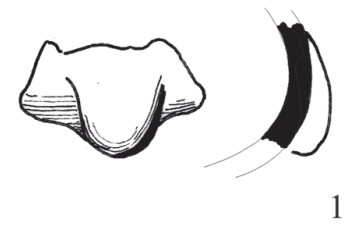

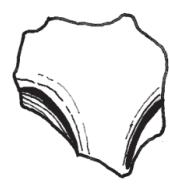

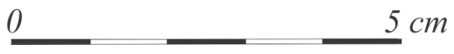

Ryc. 1. Międzyrzecz, stan. 1, gród. Fragmenty średniowiecznych naczyń szklanych z poziomu osadniczego z okresu 1269 - lata 80. XIII wieku

wy zaczął się około połowy XIV wieku (Kurnatowski 2015). Kończył się wówczas długi okres użytkowania założenia grodowego.

\section{PODSTAWA ŹRÓDŁOWA}

Międzyrzecki zbiór średniowiecznych naczyń szklanych zawiera około 530 niewielkich fragmentów naczyń stołowych - pozyskanych jednak z dobrze udokumentowanych i niezaburzonych poziomów osadniczych grodu, $\mathrm{z}$ wykopu $\mathrm{nr}$ I założonego na majdanie grodu.

Stan zachowania tego zbioru nie jest zadowalający. Znaczne rozdrobnienie materiału nie pozwoliło na pełną rekonstrukcję form naczyń, a daleko posunięta korozja uniemożliwiła szczegółowe obserwacje makroskopowe (przezroczystość czy barwa szkieł) i wykonanie większej serii analiz fizykochemicznych ${ }^{2}$. O bardzo złym stanie XIII i XIV-wiecznych szkieł (daleko zaawansowana korozja) jeszcze w trakcie prac wykopaliskowych pisał w dziennikach badań Stanisław Kurnatowski. Rozważania o ewentualnym pochodzeniu naczyń można rozpatrywać jedynie na podstawie znacznie zunifikowanych $\mathrm{w}$ średniowieczu ich form. Pierwsze nieliczne znaleziska szklanych naczyń pochodzą z faz osadniczych $\mathrm{z}$ pierwszej połowy XIII w., ostatnie, pojedyncze, z fazy osadniczej datowanej na ostatnie dwudziestolecie XIV w. - czasu budowy kazimierzowskiego zamku. Z czasów egzystowania zamku pochodzi kolekcja późniejszych szkieł pozyskana podczas inwentaryzacji architektonicznej. Nie jest ona tematem tego opracowania.

\footnotetext{
${ }^{2}$ Opisując ułamki naczyń, barwę i stopień przezroczystości szkła, zamieszczano jedynie przy fragmentach nieskorodowanych.
} 


\section{KLASYFIKACJA}

Przyjęto prostą klasyfikację średniowiecznych naczyń stołowych, stosowaną od lat przez badaczy czeskich (Fryda 1991; Sedlačkova 2010; Černa, Frýda 2010) szklanice wysokie i niskie (pucharki), butelki (karafki), dzbanki i miski (tabela 1).

Tabela 1. Zestawienie w poziomach osadniczych fragmentów naczyń z grodu w Międzyrzeczu

\begin{tabular}{|c|c|c|c|c|c|c|c|}
\hline Fazy osadnicze & $\begin{array}{l}\text { Szklanice/ } \\
\text { pucharki }\end{array}$ & Miseczki & Butelki & Dzbanki & 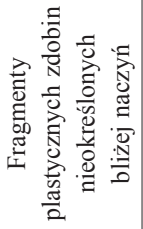 & $\begin{array}{l}\text { Nieokre- } \\
\text { ślone }\end{array}$ & Razem \\
\hline XIII w. do 1269 r. & & & & & 1 & 3 & 4 \\
\hline 1269- lata 80. XIII w. & & 1 & & & 4 & 28 & 33 \\
\hline $\begin{array}{l}\text { Lata } 80 . \text { XIII w. - } \\
1 \text { poł. XIV w. }\end{array}$ & 7 & 1 & 1 & & 7 & 127 & 143 \\
\hline $\begin{array}{l}\text { Poł. XIV - } 2 \text { poł. } \\
\text { XIV w. }\end{array}$ & 35 & 1 & & & 20 & 108 & 164 \\
\hline $\begin{array}{l}\text { Koniec } 3 \text { i początek } \\
4 \text { ćw. XIV w. }\end{array}$ & 10 & & & 2 & 18 & 156 & 186 \\
\hline Razem & 52 & 3 & 1 & 2 & 50 & 422 & 530 \\
\hline
\end{tabular}

\section{Szklanice i pucharki}

Są to najczęściej spotykane późnośredniowieczne naczynia stołowe. Zdobione są ornamentem plastycznym - przeważnie guzowym, nakładanym często wraz $\mathrm{z}$ nitką szklaną. W zbiorze z Międzyrzecza do tej grupy zaliczono 52, podobnie jak na wielu innych średniowiecznych stanowiskach, jedynie ułamki tych naczyń. Rozważania o typologii możliwe są tylko w stopniu ograniczonym - jedynie w kilku przedstawionych poniżej przypadkach można było bliżej określić przypuszczalną formę naczynia.

Z małymi wyjątkami można zaliczyć te pozostałości do grupy niskich pucharków. Reprezentują różne kształty brzuśców - proste cylindryczne, koniczne i owoidalne. Często mają wywinięty wylew z pogrubioną krawędzią i prawie zawsze stopkę utworzoną przez dolepienie wałka lub rzadziej płaskiej listwy. Czytelne w kilku przypadkach dna są wepchnięte do wewnątrz. Zdobienia to guzy, sople i nitki - charakterystyczne dla średniowiecznych naczyń, w tym przede wszystkim dla pucharków i szklanic. 


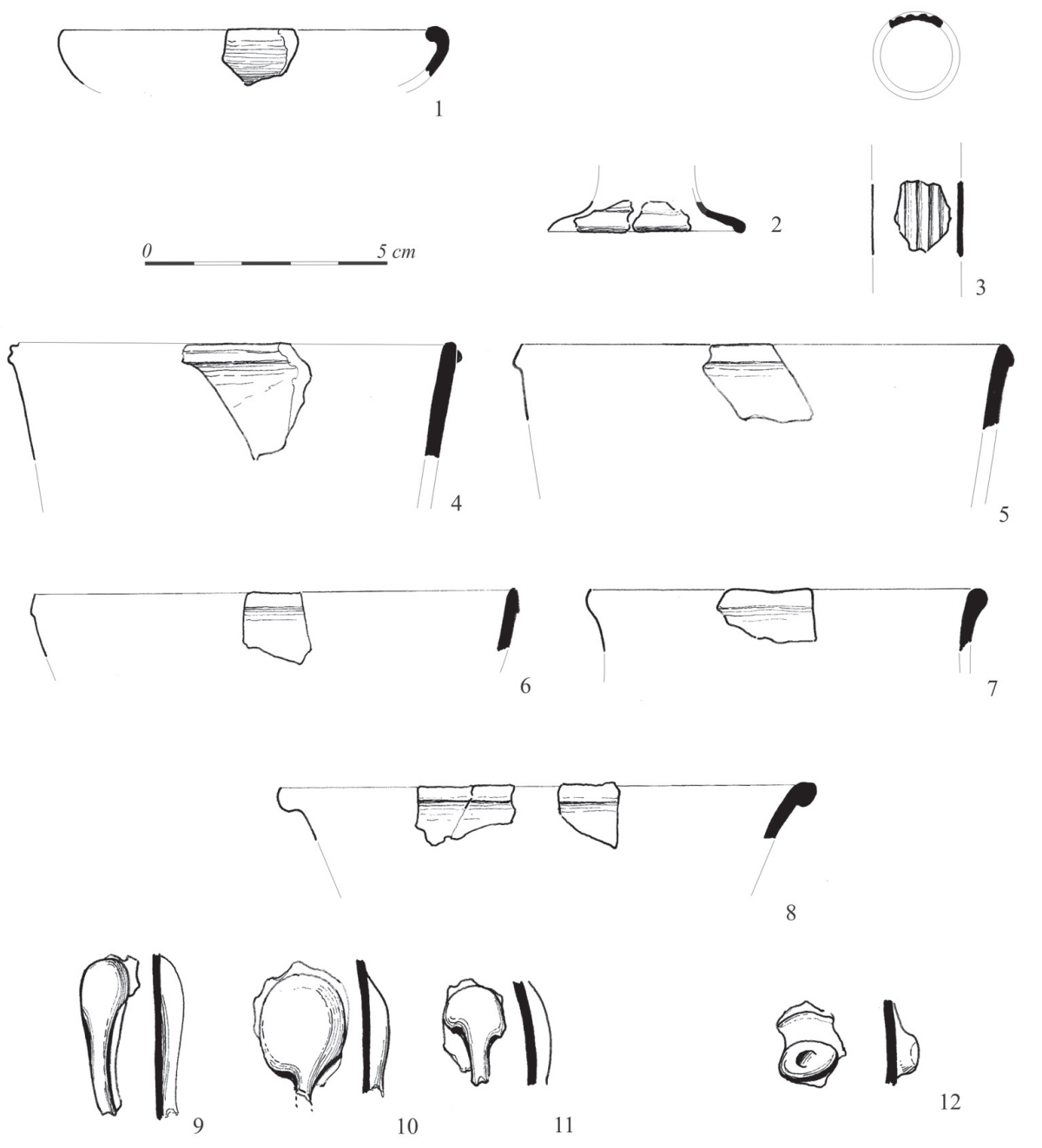

Ryc. 2. Międzyrzecz, stan. 1, gród. Średniowieczne naczynia szklane z poziomu osadniczego $\mathrm{z}$ lat 80 . XIII - 1 poł. XIV wieku

Guzy reprezentują trzy główne typy charakterystyczne dla naczyń z tego okresu, określone przez Jerzego Olczaka (Olczak, Jasiewiczowa 1963, s. 81). Wykonano je, nalepiając bryłki szkła na korpus naczynia i tam formując do odpowiedniego kształtu:

- małe (o średnicy około $0,5 \mathrm{~cm}$ ), lekko skręcone guzki typu $a$, wystąpiły na fragmentach brzuśców bliżej niekreślonych naczyń oraz na dwóch naczyniach, których formę można było bliżej określić - pucharku typu Schaffhauser (ryc. 3.1) 
zdobionym dodatkowo kobaltową listwą i na dużej cylindrycznej szklanicy (ryc. 4.4). Tego typu guzki pojawiają się w ostatniej ćwierci XIII w. na naczyniach produkowanych w północno-wschodniej Europie - głównie w hutach czeskich i południowoniemieckich. Inspiracją dla tego typu zdobień, szczególnie dla większych guzków, były pucharki islamskie (Medieval glass... 2010, s. 124). Naczynia zdobione tego typu guzami to różnego rodzaju niskie szklanice o rozchylonych wylewach lub późniejsze wysokie szklanice fletowate. Współczesne okazom międzyrzeckim są znaleziska ze Śląska (Biszkont 2005; Siemianowska 2015a), Elbląga i Torunia (Gołębiewski 1992; Nawrolska 2008), Krakowa (Kraków... 2007),

- większe guzki (o średnicy nawet $1,5 \mathrm{~cm}$ ) typu $c$ - na soplach nalepionych na korpus naczynia. Spływające szkło zostało w dolnej partii uformowane w zakręcony guzek (ryc. 3;18,19). W Międzyrzeczu odkryto jedynie małe fragmenty takich guzków. Liczniej występują na Śląsku (Biszkont 2005, s. 31). Na podstawie znalezisk tego typu guzków na naczyniach $\mathrm{z}$ czeskiego Mostu zrekonstruowano pucharek o konicznym brzuścu i wylewie zdobionym dodatkowo nicią szklaną. Uważa się, że jest to import z hut niemieckich (Černa 1997, s. 338),

- guzki typu $d$ - sople - są wyznacznikiem określonego typu naczyń - pucharków typu Rippenbecher, które zostały omówione poniżej.

Ornamenty nici szklanej, zachowane przeważnie w ułamkach, to przede wszystkim plastyczne listwy nalepione tuż pod krawędzią, w dwóch przypadkach zdobione karbowaniem (ryc. 3:2,13), w jednym ze szkła barwy ciemnoniebieskiej (prawdopodobnie barwionym tlenkiem kobaltu). Odnotowano również zdobinę w postaci płaskiej listwy ze szkła innej barwy (nieczytelna) tuż pod wylewem (ryc. 3:9). Zdobienie przyspajaną, przeważnie poziomą nitką szklaną, czasami o różnej grubości i w różnej konfiguracji, występuje u naczyń różnych typów (flasze, wysokie szklanice, dzbany). W Elblągu w nawarstwieniach z przełomu XIII i XIV w. znaleziono szereg ułamków zdobionych plastyczną listwą, zastosowaną, zarówno jako zdobina korpusu, jak i przy formowaniu stopki przy niskich pucharkach do picia oraz poziomo często przy przejściu szyjki w brzusiec (Gołębiewski 1992, tab. 1 i 4). W Międzyrzeczu ułamki tak zdobionych naczyń są zachowane fragmentarycznie.

Niewielki fragment naczynia zdobionego prostą nitką szklaną przy przejściu szyjki w brzusiec odkryto w poziomach osadniczych z 1 . połowy XIII w. i został przebadany fizykochemicznie (tabela 2). Ten fragment znaleziono wraz z niewielkim (o średnicy około $12 \mathrm{~mm}$ ) plastycznym guzkiem utworzonym przez wyciągnięcie z korpusu naczynia, wykonanym z czarnego nieprzejrzystego szkła ${ }^{3}$. Są to najwcześniejsze, pojedyncze znaleziska szklanych naczyń na tym stanowisku.

Z nici i wałeczków szklanych różnych rozmiarów i kształtów, a w kilku przypadkach nici podwójnej, uformowano stopki. W jednym przypadku nić tworząca

\footnotetext{
${ }^{3}$ Guzek typu $b$ według J. Olczaka, Olczak, Jasiewiczowa 1963, s. 81.
} 

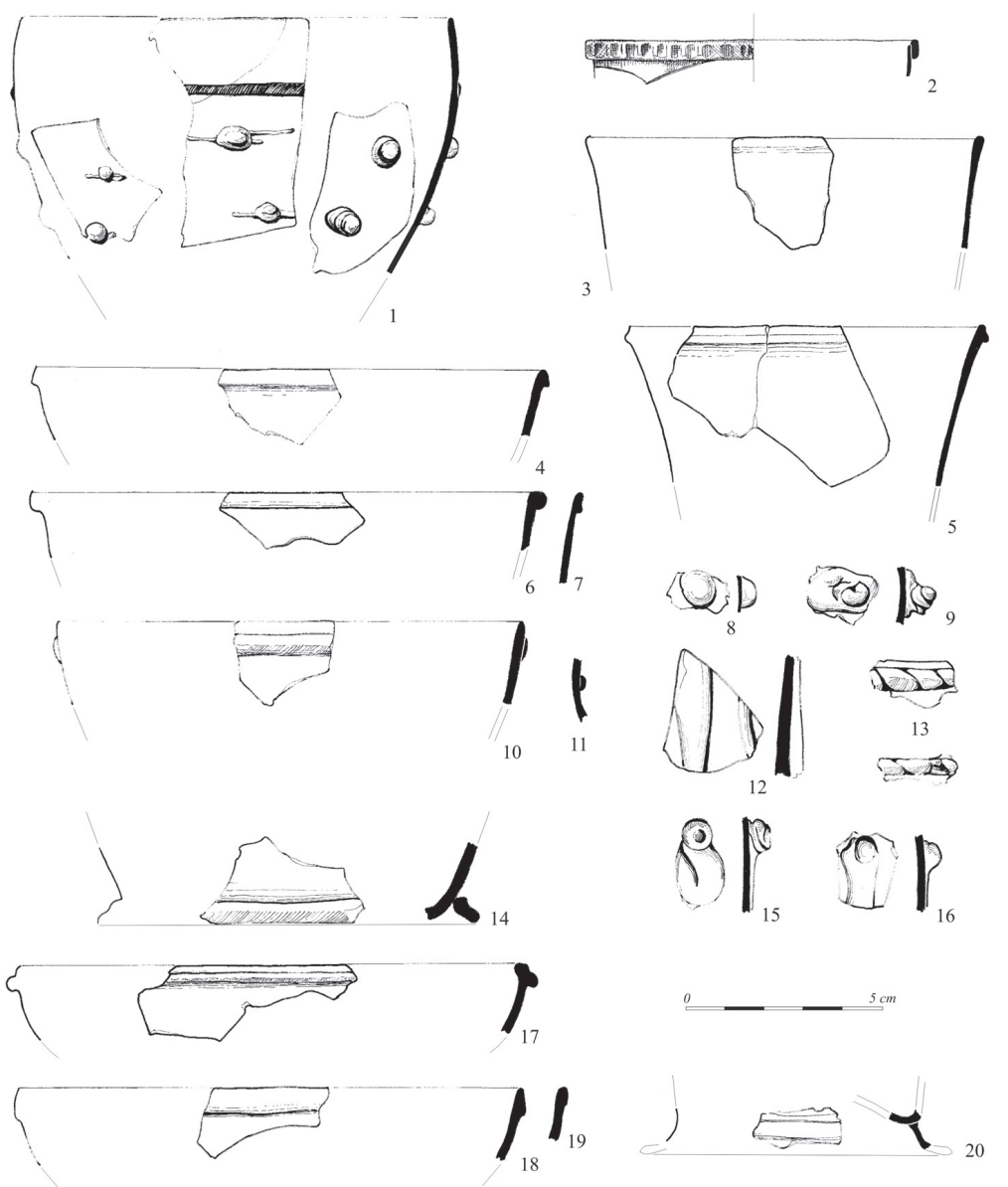

cos
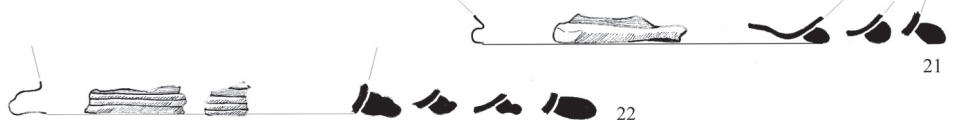

Ryc. 3. Międzyrzecz, stan. 1, gród. Średniowieczne naczynia szklane z poziomu osadniczego z poł. XIV wieku

stopkę jest uformowana narzędziem w ornament „perełkowy” (ryc.4:3) i w kilku innych niewielkich fragmentach pokarbowana. Stopki utworzone z nici, wałka czy plastycznej listwy są powszechnie spotykane w różnych typach stołowych naczyń. Podobnie karbowane stopki w XIII i XIV w. występują w różnego rodzaju niskich pucharkach. Razem z miseczkowatymi wylewami znalezionymi w Międzyrzeczu można takie stopki hipotetycznie łączyć z pucharkami określonymi przez F. Frydę jako typ IV, lub inaczej Schaffhauser Becher - różnych typów niskie pucharki 
z guzami i wylewem wyraźnie oddzielonym od brzuśca nicią szklaną. Liczne znaleziska tych naczyń znane są z ośrodków miejskich z Niemiec, Szwajcarii (Medieval Glass... 2010; Arndt 2008, s. 177; Röber 2008, s. 433). Takie naczynia produkowano od XI/XII w. w Koryncie i później prawdopodobnie na terenach włoskiej Apulii. W Europie zaalpejskiej znane są od XIV w. (Harden 1966, s. 71). $\mathrm{Na}$ uwagę zasługuje fragment stopki mającej charakter odpadu produkcyjnego uformowanej przez dolepienie do korpusu naczynia okrągłej, pokarbowanej, o średnicy $4 \mathrm{~mm}$, nici szklanej. Korpus i nić są zniekształcone (ryc. 4:7).

Wzmiankowany wyżej stan zachowania fragmentów naczyń z Międzyrzecza pozwolił przedstawić poniżej próbę rekonstrukcji jedynie kilku typów naczyń.

Pucharki typu Schaffhauser (Schaffhauser Becher) - określane tak w literaturze niemieckiej (Baumgartner 1987, s. 51). František Fryda określił je jako typ IV čiše s nálepy (1991, s. 243). Są to niskie pucharki z różnie ukształtowanym wylewem, zdobione różnej wielkości guzkami typu ,a” i nitką szklaną, często oddzielającą wylew od brzuśca. Stopki wykonane są z zawiniętej plastycznej nici, niekiedy pokarbowanej, dna wepchnięte do środka. $Z$ jednym $\mathrm{z}$ wariantów tego typu naczyń (IV 3) można łączyć znaleziony w poziomie osadniczym z połowy XIV - 2. połowy XIV w. fragment pucharka o lekko pękatym brzuścu i nachylonym do wewnątrz brzegu. Średnica brzegu $11 \mathrm{~cm}$, grubość ścianki $1,5 \mathrm{~mm}$. Brzeg jest zaokrąglony i poniżej krawędzi zdobiony plastyczną, lekko spłaszczoną ciemnoniebieską nicią szklaną (prawdopodobnie ze szkła barwionego związkami kobaltu). Poniżej tej listwy brzusiec jest zdobiony pojedynczymi, plastycznymi, nalepionymi guzkami uformowanymi przez zakręcenie pasma szkła. Szkło białe, przezroczyste z lekką powierzchniową korozją (ryc. 3:1, 5:3).

Kilka fragmentów większych guzków mogło należeć do pucharków ogólnie znanych jako Nuppenbechery, produkowane w niemieckich hutach od XIII w., których odmianą jest opisany powyżej pucharek typu Schaffhauser.

Naczynia różnych wariantów tego typu znajdowane są przede wszystkim na obszarach Czech, Niemiec, Szwajcarii ${ }^{4}$ w poziomach osadniczych z XIV-XV wieku. W Polsce znajdowano je na Śląsku (Wrocław, Legnica, Lwówek Śląski Biszkont 2005, s. 30), w Elblągu (Gołębiewski 1992, s. 474, ryc. 2:2), Nakle i Świeciu (Ciepiela 1971a, s. 208; 1971b, s. 480). Pucharek o cylindrycznym korpusie z „kielichowatym”, prawdopodobnie konicznym brzegiem i guzkami typu a znaleziono w XIV-wiecznych poziomach osadniczych Krakowa (Kraków... 2007, s. 455). Zdobienie kobaltową nicią spotykane jest często na naczyniach z terenu Niemiec, Szwajcarii, Czech, niekiedy produkcję bezbarwnych naczyń zdobionych kobaltową nicią wiąże się z hutami czeskimi (Steppuhn 2016, s. 61). Występuje w różnej konfiguracji. Wylew podobnego pucharka datowanego na początek XV w.

\footnotetext{
${ }^{4}$ O pucharkach tego typu i próbie systematyki bliżej J. Biszkont $(2005$, s. 29) i tam dalsza literatura.
} 
znaleziono w Lüneburgu (Glaskultur... 2003, s. 61). W zespole naczyń z Bratysławy podobny okaz o lekko beczułkowatym korpusie datowano na XIII-XIV w. (Sedlačkova, Rohanová, Lesák, Šimončičová-Koóšová 2014, fig. 16:9). Naczynie z Międzyrzecza, wykonane z przezroczystego, białego, dobrze wyklarowanego szkła bardzo dobrej jakości, było produktem luksusowym wysoko wyspecjalizowanej huty.

Pucharki z pionowymi żeberkami (ribbed beakers, čišky s taženými kapkami, Rippenbecher) Wyznacznikiem tego typu naczyń, o różnych kształtach, jest charakterystyczny plastyczny ornament $\mathrm{w}$ postaci nalepionych długich sopli, niekiedy dodatkowo zdobionych guzkami szkła innej barwy. Sople takie - guzki typu $d$ według J. Olczaka - występujące na brzuścu naczynia w układzie wertykalnym powstają przez natapianie na korpus naczynia bryłek szkła, które kształt uzyskiwały przez spłynięcie do stopki. Stopkę formowano przez nawinięcie, niekiedy wielokrotnej, nici. Jest to najbardziej charakterystyczny typ średniowiecznych niskich szklanic na północ od Alp.

Najstarsze naczynia tego typu pojawiają się w Europie w XII w., a rozpowszechniają w wiekach XIII-XV (Haggrén, Sedláčkova 2007; Schütte 1983). Znajdowane są na terenie środkowej Europy, Czech, Moraw, Pomorza, Estonii. Od połowy XIII w. łączy się je z zachodnioczeskimi hutami i z niektórymi pracowniami niemieckimi. Jednoznacznie określane są jako wyrób luksusowy - dla bogatego patrycjatu i szlachty. Znany jest przypadek użycia takiego pucharka jako relikwiarza - w klasztorze w Rehnie w Meklemburgii (Haggrén, Sedláčkova 2007, s. 244 i n.). Naczynia takie znaleziono w warstwach z 1. ćwierci XIV w. w Toruniu i Elblągu (Gołębiewski 1992, s. 474), Świeciu, Krakowie i Warszawie (Ciepiela 1971a). Więcej znalezisk pochodzi z terenów Śląska - z klasztoru w Jaworze, Legnicy i z Wrocławia (Biszkont 2005; Haggrén, Sedláčkova 2007, s. 192; Siemianowska 2015, s. 139).

Pucharki z Międzyrzecza zachowały się w niewielkich fragmentach. Nie można bliżej określić ich formy. Ornament reprezentuje prostszą odmianę - bez nalepionych na soplach niewielkich guzków. Fragmenty tych naczyń pojawiają się w Międzyrzeczu w nawarstwieniach powstałych po 1269 r. i hipotetycznie można zaliczyć je do wcześniejszych form - niskich szklanic o owoidalnym brzuścu i prawdopodobnie miseczkowatym wylewie (ryc. 1:2,3; 2:9-11 i ryc. 5:1). Cztery niewielkie ułamki guzków znaleziono również w późniejszych nawarstwieniach z 2. połowy XIV wieku (ryc. 4:9). Również i w tym przypadku nie można określić formy naczynia, podobnie jak w przypadku dwóch miseczkowatych cienkościennych wylewów, o średnicy około $13 \mathrm{~cm}$, charakterystycznych dla tego typu naczyń. Jeden $\mathrm{z}$ dobrze zachowanych fragmentów wykonany został z oliwkowozielonego, przezroczystego szkła „leśnego” (ryc. 3:18,19). 


\section{Pucharki bez ornamentu}

W zbiorze fragmentów naczyń z Międzyrzecza jedno z częściowo zrekonstruowanych naczyń to niski pucharek bez zdobin o prostym, lekko wydętym brzuścu i zaokrąglonym brzegu. Dno wepchnięte $\mathrm{z}$ wyraźnym śladem przylepiaka i spłaszczonym dookolnym wałeczkiem. Średnica brzegu $11 \mathrm{~cm}$, przybliżona wysokość $11 \mathrm{~cm}$. Naczynie wykonano z zielonooliwkowego „leśnego”, przezroczystego szkła. Zostało znalezione w poziomie osadniczym z końca 3. i początku 4. ćwierci XIV wieku. Pucharki bez ornamentu, datowane na wiek XV znalezione w Elblągu i Wrocławiu (Biszkont 2005, s. 39), różniły się jednak od egzemplarza międzyrzeckiego, który przypomina niezdobione pucharki znane po połowie XIV w. z terenu Moraw, produkowane w miejscowych hutach (Sedláčkova 2010, s. 363).

\section{Szklanice wysokie, fletowate}

Szklanice fletowate są uznawane przez badaczy czeskich za najbardziej powszechną formę szklanych naczyń stołowych w Czechach w średniowieczu (čiše českeho typu, pištalove, kyjovité). Powszechne są w tym czasie również na obszarach Niemiec, gdzie formy i zdobiny określają ich nazwy - Keulenglas, Stangenglas, Passglas. Przypuszcza się, że pierwotnie naczynia te sprowadzono do Europy przez rycerzy zakonu krzyżackiego z Syrii lub Palestyny, u schyłku XIII wieku. W Czechach pojawiają się w tym samym czasie jako produkty miejscowe i stają się typowym dworskim i mieszczańskim naczyniem stołowym (Markiewicz 1989, s. 21). Grupa szklanic fletowatych obejmuje różne warianty tych naczyń o odmiennych formach i rozmiarach (koniczna, maczugowata) czy zdobieniach (różne rodzaje guzków). Wysokie i bardzo wąskie, lekko stożkowate szklanice, według typologii F. Frydy (typ I.1), pojawiają się przed połową XIV wieku.

Do szklanic wysokich w zbiorze $\mathrm{z}$ Międzyrzecza zaliczono dwa przydenne fragmenty reprezentujące odmienne typy naczyń. Pierwszy z nich to fragment stopki małej i bardzo wąskiej szklanicy. Średnica stopki wynosi $4,5 \mathrm{~cm}$, brzuśca około 2,5 cm. Naczynie jest cienkościenne, stopkę, która nie zachowała się w całości, wykonano z płaskiej listwy. Fragmenty te odkryto w nawarstwieniach datowanych między rokiem 1269 a latami 80. XIII wieku (tablica 2:2). Wcześniejszy okaz takiej szklanicy, datowany hipotetycznie na 2. połowę XIII w. znaleziono w Głogowie (Biszkont 2005, s. 58). W przypadku naczynia z Międzyrzecza można przyjąć, że reprezentuje starszą formę, co może tłumaczyć nietypową (małą) stopkę. Okazy o porównywalnych średnicach brzuśca, wąskie i wysokie odkryto na Śląsku - w Nysie i Legnicy, w Elblągu czy saksońskim Freibergu (Biszkont, tab. 25;b, 27;c, tab. 20;a, s. 70; Nawrolska 2008, s. 514; Beutmann 2014 s. 150, ryc. 2;16). Miały około $3 \mathrm{~cm}$ średnicy, jednak znacznie szerszą stopkę, uformowaną przez nalepienie płaskiej listwy, i pochodziły z XIV wieku. Oprócz licznych znalezisk ze Śląska, szklanice fletowate są powszechnie spotykane w XIV i XV w., zarówno na stanowiskach miejskich, jak i zamkach i dworach. Młodsze egzemplarze 

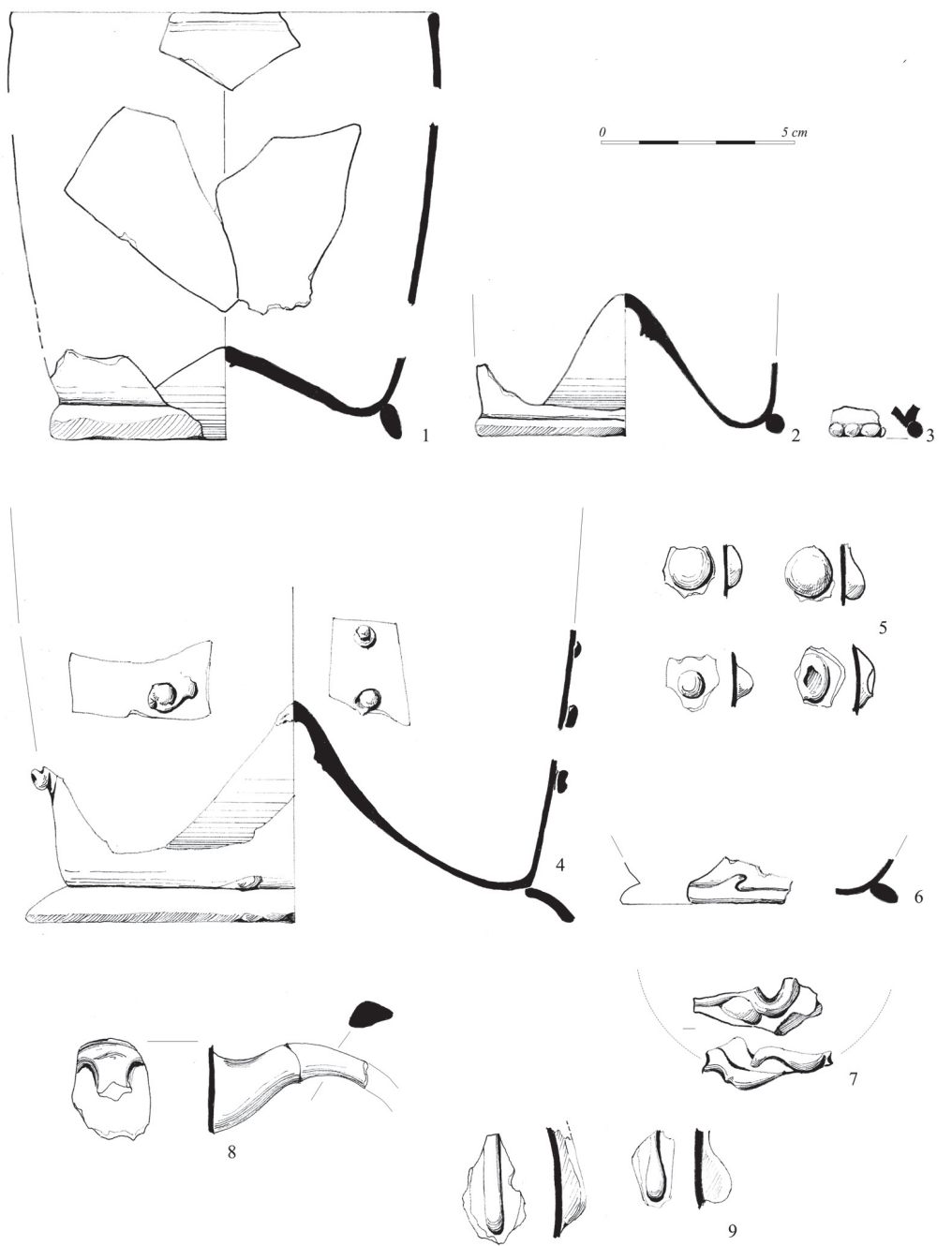

Ryc. 4. Międzyrzecz, stan. 1, gród. Średniowieczne naczynia szklane z poziomu osadniczego z końca 3 i początku 4 ćwierci XIV wieku

występowały w Polsce jeszcze w XVII wieku (Olczak 1999, s. 86). Opinia badaczy o pochodzeniu szklanic fletowatych odkrytych w Polsce jest podzielona. Przebadano fizykochemicznie dziewięć fragmentów takich naczyń ze Starego Miasta w Warszawie (datowanych od 2. połowy XV do 1. ćwierci XVII wieku). Badania wykazały, że prawie wszystkie egzemplarze zostały wyprodukowane z lokalnych surowców w różnych krajowych hutach, a tylko jeden egzemplarz pochodzi prawdopodobnie z Czech (Ciepiela 1991, s. 37-39). W przypadku wczesnego znaleziska z Międzyrzecza trzeba przyjąć, że było importem. W pucharach fletowatych pito 
zapewne piwo, na co wskazują źródła ikonograficzne (Biszkont 2005, s. 54; Ciepiela 1971c, s. 208).

Drugi z odkrytych w Międzyrzeczu fragmentów to zachowana w całości stopka (o średnicy $13 \mathrm{~cm}$ ) dużej, prawdopodobnie wysokiej, cienkościennej (grubość ścianki $1 \mathrm{~mm}$ ) i szerokiej szklanicy - o prawdopodobnie cylindrycznym brzuścu. Stopa uformowana przez dolepienie do korpusu naczynia płaskiej, wyprofilowanej listwy (długość $13 \mathrm{~mm}$ ) - z zachowanym śladem zawinięcia. Dno zostało wepchnięte do wewnątrz, zachował się ślad przylepiaka. Naczynie jest zdobione niewielkimi guzkami (zachowały się cztery) typu $a$, powstałymi przez zakręcenie pasma szkła. Układ guzków jest nieczytelny. Szkło jest białe, przezroczyste, o lekko żółtym zabarwieniu (ryc. 4:4). Naczynie pochodzi z poziomu datowanego na koniec 3. i początek 4. ćwierci XIV wieku.

Przypomina określony przez F. Frydę typ wysokiej szklanicy o szerokiej podstawie (typ II), baniastym w górnej części brzuścu, zdobionym guzkami (Fryda 1991, s. 240 i tab. 1/2). Formą nawiązuje również do szerokich szklanic typu I 5 i podobnie jak one, w materiałach $\mathrm{z}$ terenu Czech występuje od 2. połowy XIV do połowy XV wieku.

\section{Butelki, dzbanki}

Wspomniany na wstępie zły stan zachowania naczyń z Międzyrzecza, w tym również znaczne rozdrobnienie materiału nie pozwoliło na rekonstrukcje tych naczyń. Do grupy tej zaliczono jedynie trzy niewielkie fragmenty, które można określić jako pozostałości butelki i dzbanków.

\section{Butelka (?)}

Odkryto niewielki fragment cylindrycznej szyjki o średnicy $2 \mathrm{~cm}$, zdobionej delikatnymi, płytkimi pionowymi żłobkami uformowanymi przez odciśnięcie w formie. Naczynie jest cienkościenne - grubość ścianki wynosi $1 \mathrm{~mm}$, przez daleko posuniętą korozję nie można odczytać barwy szkła. Fragmenty te odkryto w poziomie osadniczym datowanym na 2. połowę XIII wieku (ryc. 2:3, 5:2).

Zdobienie szyjek butelek $\mathrm{z}$ odciskanym $\mathrm{w}$ formie żłobkowaniem w różnych układach (prostym, diagonalnym) było powszechne dla tych naczyń w XIII i XIV wieku. Przeważa jednak, obok prostych i niezdobionych szyjek, ornament z nawiniętej plastycznej nici (Stiaffini 1999, s. 110; Historie... s. 79 i n. ). Butelki XIII -wieczne, ze zdobionymi $\mathrm{w}$ ten sposób szyjkami, produkowane były przez warsztaty weneckie, a znajdowane na terenie niemal całej Europy (Gasparetto 1975). Tak jak w przypadku niektórych innych typów szklanych naczyń czy rodzajów ich zdobnictwa, impulsy i wzorce przywieziono z Palestyny, a warsztaty weneckie czy śródziemnomorskie adaptowały te formy dla terenów Europy w tym do najbliższych Wielkopolsce warsztatów czeskich czy niemieckich. W czes- 
kich hutach butelki zaczęto produkować od przełomu XIII/XIV w. - wcześniejsza butelka z Międzyrzecza mogła więc powstać w innych zachodnioeuropejskich pracowniach. Znaczny stopień korozji nie pozwolił na przeprowadzenie badań składu chemicznego; badania takie mogłyby uszczegółowić rozważania o jej pochodzeniu. Nie można określić jednoznacznie formy, zapewne miała baniasty brzusiec i wysoką szyjkę. Szyjki butelek zdobionych podobnym ornamentem znajduje się często na Śląsku, są one jednak trochę późniejsze i z lekko ukośnym plastycznym ornamentem, odciśniętym w formie - np. na staromiejskich stanowiskach w Jeleniej Górze. Są jednak nieco późniejsze od międzyrzeckich (datowane na XIV-XVI wiek - Biszkont 2005, tab. 10e).

\section{Dzbanki}

W przypadku tych naczyń wyznacznikiem typu były dwa skorodowane ułamki podobnych do siebie taśmowatych uch. Dzbanki były cienkościenne (grubość ścianek około $1 \mathrm{~mm}$, szerokość uch 10-11 mm, grubość około $6 \mathrm{~mm}$ ). Jedno z nich było zdobione delikatnym pionowym żeberkiem (ryc. 4:8). Również i w tych przypadkach nie można określić zarówno formy naczynia, jak i barwy szkła. Fragmenty te odkryto w nawarstwieniach z końca 3. i początku 4. ćwierci XIV wieku.

Takie wczesne znaleziska rzadko są spotykane w Polsce - fragmenty dzbanka z 2. połowy XIV w. znaleziono w Toruniu (Gołębiewski 1998, s. 217). Dzbanek $\mathrm{z}$ taśmowatym uchem znaleziono w czeskim Moście (Historie..., s. 102). Podobnie datowany na 2. połowę XIV w. dzbanek z Kutnej Hory uważany jest za import (Biszkont 2005, s. $40 \mathrm{i}$ tam dalsza literatura). Importem są dzbanki z 2. połowy XIII i połowy XIV w., ze zdobionymi uchami z Brna i Bratysławy (Sedlačkova 2003, tab.1; Sedlačkova H., Rohanová D., Lesák B. Šimončičová-Koóšová P. 2014, s. 246). Przed wiekiem XV były to znaleziska raczej rzadkie również na terenie Niemiec (Rademacher 1933, s. 73-74).

\section{Miseczki (?)}

Odkryto trzy niewielkie fragmenty naczyń, które hipotetycznie można określić jako pozostałości miseczek:

- niewielki fragment mocno wydętego brzuśca małej, grubościennej (3 mm) miseczki (?) o nieczytelnej średnicy, zdobionej pionowymi plastycznymi nalepianymi żeberkami (ryc. 1:1). Barwa szkła nieczytelna. Pochodzi z poziomu osadniczego datowanego na 1 . połowę XIII w. do roku 1269,

- fragment brzegu niewielkiej miseczki o średnicy 7-8 cm, krawędzi zaokrąglonej i zagiętej do wewnątrz. Grubość ścianki $2 \mathrm{~mm}$. Barwa szkła nieczytelna. Odkryty w poziomach osadniczych datowanych od 1269 r. do lat 80 . XIII wieku (ryc. 2:1), 
- fragment wylewu miseczki (?). Krawędź pogrubiona przez zagięcie brzegu i uformowanie formą. Średnica brzegu $-13 \mathrm{~cm}$, grubość ścianki - $2 \mathrm{~mm}$ (ryc. 3:17). Datowana na połowę -2 . połowę XIV wieku.

Fragmenty te zachowały się $\mathrm{w}$ niewielkich ułamkach, bez części przydennych, określających jednoznacznie formę naczynia. Znane są miseczki z pionowymi plastycznymi nalepionymi żeberkami z terenu Moraw, datowane na lata 1200-1350 (Sedlačkova 2010, s. 361). Często również zachowane fragmentarycznie miski, zdobione plastycznym ornamentem należą do misek na niskiej nóżce, datowanych na XIV-XV stulecie (Historie... 2005, s. 89; 102, Sedlačkova 2003, taf. 1-2). Można je również łączyć ze znaleziskami gobletów na wysokiej nóżce, które czasami mają miseczkowate korpusy i zdobiny w postaci plastycznych wertykalnych żeberek (Stiaffini 1999, s. 105, Historie..., tab. 11).

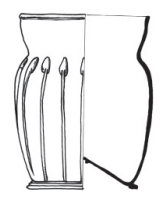

1

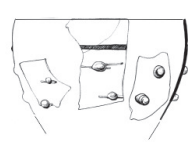

2

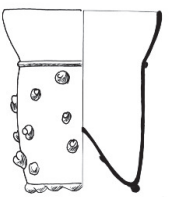

3

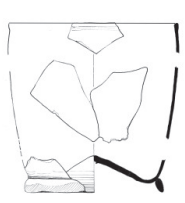

4

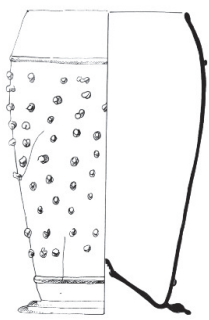

5

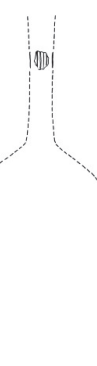

6

Ryc. 5. Międzyrzecz, stan. 1, gród. Próba rekonstrukcji form średniowiecznych naczyń odkrytych w Międzyrzeczu

\section{NACZYNIA NIEOKREŚLONE}

Stanowią znaczny odsetek znalezisk (tabela 1). Siedemnaście fragmentów stopek, które zachowały się najlepiej, a właściwie dookolnych dolepionych listew, można łączyć z niskimi szklankami/pucharkami. Podobnie 27 małych fragmentów zaokrąglonych brzegów. Przeszło 370 fragmentów to bardzo małe fragmenty niezdobionych, przeważnie cienkościennych brzuśców, których nie można powiązać z żadnym z typów naczyń. Można jedynie stwierdzić, że ta w przeważającym stopniu skorodowana stłuczka szklana pochodzi od cienkościennych naczyń stołowych. 


\section{BADANIA FIZYKOCHEMICZNE}

Badacze szkła średniowiecznego i nowożytnego duże nadzieje pokładają w badaniach laboratoryjnych składu chemicznego szkła. Ich wyniki, pozwalające określić skład chemiczny szkła i zrekonstruować szklarską recepturę, mogą niekiedy pomóc $\mathrm{w}$ ustaleniu ośrodka bądź regionu wytwórczego. Stan badań nad wytwórczością szklarską w okresie późnośredniowiecznym nie jest w Polsce, w tym również w Wielkopolsce zaawansowany, a zbiór porównawczych analiz zbyt ubogi, aby można było rozważać problem pochodzenia wyrobów szklanych, posiłkując się takimi analizami. Dla materiałów z Międzyrzecza, w tym także dla naczyń wykonano serię analiz fizykochemicznych. Wcześniejsze analizy opublikowane i zinterpretowane przez J. Olczaka (1995) zostały wykonane metodą analizy spektralnej ilościowej, obecnie już nieużywaną i mało porównywalną i dlatego w niniejszym opracowaniu przedstawiono tylko interpretację Autora. Przebadane fragmenty nie zachowały się i nie można było powtórzyć analiz.

Zaprezentowane przez J. Olczaka trzy niewielkie fragmenty określano jako:

- fragment brzegu nieokreślonego bliżej naczynia, pochodzącego z poziomu osadniczego z końca XIII w., o prawdopodobnie beczułkowatym korpusie i pogrubionej krawędzi, szkło żółte przezroczyste typu $\mathrm{PbO}-\mathrm{SiO}_{2}$ (ołowiowo-krzemowe),

- fragment przepalonego wtórnie nieokreślonego naczynia $\mathrm{z}$ poziomu osadniczego z końca XIV w., szkło bezbarwne przezroczyste typu $\mathrm{K}_{2} \mathrm{O}-\mathrm{Na}_{2} \mathrm{O}-\mathrm{CaO}-\mathrm{Al}_{2} \mathrm{O}_{3}$ - $\mathrm{MgO}-\mathrm{SiO}_{2}$ (potasowo-sodowo-wapniowo-glinowo-magnezowo-krzemowe),

- fragment niekreślonego naczynia, szkło bezbarwne przezroczyste typu $\mathrm{Na}_{2} \mathrm{O}+\mathrm{K}_{2} \mathrm{O}-\mathrm{CaO}-\mathrm{SiO}_{2}$ (alkaliczno-wapniowo-krzemowe), pochodzące prawdopodobnie z warstwy późnośredniowiecznej.

Najnowsze dwie analizy, zaprezentowanego niżej fragmentu naczynia i szyby, zostały wykonane metodą rentgenowskiej analizy fluorescencyjnej XRF (X-Ray

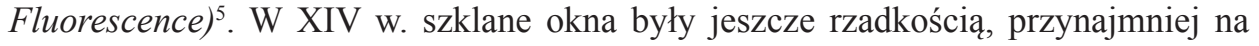
ziemiach polskich i dlatego warte są wzmianki. Są to:

- dobrze zachowany fragment szyjki cienkościennego, bliżej nieokreślonego pucharka zdobionego przy przejściu wylewu w brzusiec plastyczną okrągłą, lekko spłaszczoną nitką szklaną o średnicy $0,5 \mathrm{~cm}$. Szkło białe, przezroczyste. Pochodzi z poziomu osadniczego datowanego na 1. połowę XIII w. (ryc. 3:11). Został wykonany ze szkła typu $\mathrm{CaO}-\mathrm{K}_{2} \mathrm{O}-\mathrm{MgO}-\mathrm{SiO}_{2}$ (wapniowo-potasowo-magnezowo-krzemowego). Koncentracje głównych składników szkłotwórczych - $\mathrm{SiO}_{2}(62,68 \%)$, $\mathrm{K}_{2} \mathrm{O}(8,71 \%), \mathrm{CaO}(16,67 \%), \mathrm{MgO}(2,59 \%)$ wskazują na niskoalkaliczne szkło z dużą przewagą zawartości $\mathrm{CaO}(16,7 \%)$ nad $\mathrm{K}_{2} \mathrm{O}(8,71 \%)^{6}$. Szkło wytopiono

\footnotetext{
${ }_{5}^{5}$ Badania wykonano metodą EDS (Energy dispersive specctrometers) rentgenowskiej ilościowej analizy fluorescencyjnej XRF (X-Ray Fluorescence), w Laboratorium Bio- i Archeometrii Instytutu Archeologii i Etnologii Polskiej Akademii Nauk w Warszawie.

${ }^{6}$ Klasyfikację szkieł potasowych oparto na ustaleniach J. Ščapovej, która wydzieliła pięć stopni koncentracji głównych składników szkłotwórczych $\left(\mathrm{K}_{2} \mathrm{O}, \mathrm{CaO}, \mathrm{Na}_{2} \mathrm{O}, \mathrm{Al}_{2} \mathrm{O}\right.$ oraz $\left.\mathrm{MgO}\right)$ i na tej pod-
} 
z zestawu dwuskładnikowego (popiół i piasek). O zastosowaniu popiołu drzew, obok niskiej zawartości $\mathrm{K}_{2} \mathrm{O}$, świadczy obecność związków fosforu $\mathrm{P}_{2} \mathrm{O}_{5}$ oraz obecność związków siarki $\mathrm{SO}_{3}$ (tabela 2:1). Szkło to nawiązuje do wczesnośredniowiecznego szkła popiołowego (Holzasche Gläser), z dużym standardowym odchyleniem głównych komponentów (średnio 3,5\%), zawartością $\mathrm{K}_{2} \mathrm{O}$ od 4,3 do 14\% (średnia 9,1\%), $\mathrm{Na}_{2} \mathrm{O}-2,1-2,8 \%, \mathrm{MgO}$ - około 4\%, $\mathrm{CaO}$ - średnio $17 \%$ i niską zawartością $\mathrm{SiO}_{2}$ - około $49 \%$. Szkło takie wytapiano przede wszystkim między IX a XI wiekiem. W okresie późnego średniowiecza huty zaczęły używać innej receptury, zużywającej mniej (nawet o połowę) cennego już wówczas popiołu drzewnego, za to więcej surowca wapniowego (szkła typu Holzasche-Kalk-Gläser). Naczynie z Międzyrzecza pochodzi z huty, w której jeszcze nie przestawiono się na nową recepturę. Przyjmuje się, że przechodzenie hut na produkcję nowego szkła trwało do początków XV w. (huta w Spessart w południowych Niemczech zaczęła wprowadzać nowy typ szkła od około 1300 roku (Stephan, Wedepohl, Hartmann 1997, s. 675),

- niewielki ułamek szyby z jedną zachowaną naturalną krawędzią tafli, przezroczysty, o lekko oliwkowym zabarwieniu, grubości ponad $2 \mathrm{~mm}$, pochodzący z poziomu osadniczego z lat 80 . XIII - 1. połowy XIV w., znaleziony przy ścianie budynku (chata 1). Szybę wykonano z innej odmiany szkieł potasowych $-\mathrm{CaO}$ $-\mathrm{K}_{2} \mathrm{O}-\mathrm{MgO}-\mathrm{Al}_{2} \mathrm{O}_{3}-\mathrm{SiO}_{2}$ (wapniowo-potasowo-magnezowo-glinowo-krzemowego), o dużej zawartości CaO, zbliżonej do późnośredniowiecznego szkła popiołowo -wapniowego (Holzasche-Kalk Gläser), niskoalkalicznego, trójskładnikowego, wytapianego z popiołu, piasku i surowca wapniowego (tabela 2:2). Zawiera niższe koncentracje $\mathrm{K}_{2} \mathrm{O}$ (około 6-7\%) i wysokie $\mathrm{CaO}$ (do przeszło 25\%) - (Wedepohl 1998 , s. $13-26 ; 2003 ; 2010$, tab. 1). Szkło tej odmiany najczęściej wytwarzano w późniejszych ośrodkach wschodniowielkopolskich (Mucha 2000, s. 261-263 tab. 3; 2017, s. 326). Można łączyć je z produkcją nowożytną, przynajmniej na ziemiach polskich, produkowano je na terenie Niemiec nie tylko w okresie późnego średniowiecza, ale również przed XIV wiekiem. W starej Lubece odkryto szyby z tej odmiany szkła potasowego z poziomów osadniczych przełomu XII i XIII w. (Steppun 2016, s. 394).

Receptura szkieł potasowych polega na zastosowaniu jako topnika popiołu roślin kontynentalnych lub wyrabianego z nich potażu. Przyjmuje się, że zaczęto ją stosować w VIII-IX w. na północnym zachodzie Europy. Sposób uzyskiwania jednej z odmian takiego szkła przekazał w swoim traktacie Teofilus (Teofil Prezbiter 1998, s. 38). Szkło takie stało się podstawowym produktem w pracowniach-hutach w północnej Europie między XI a XV wiekiem. W Wielkopolsce znaleziska średniowiecznych hut szklanych są niezmiernie rzadkie, przebadany fizykochemicznie

stawie wydzieliła osiem typów szkieł potasowo-wapniowych występujących w Europie Zachodniej w średniowieczu. Bliżej o klasyfikacji szkieł potasowych - Ščapova 1973, Dekówna 1980, Wedepol 1998, 2003. 


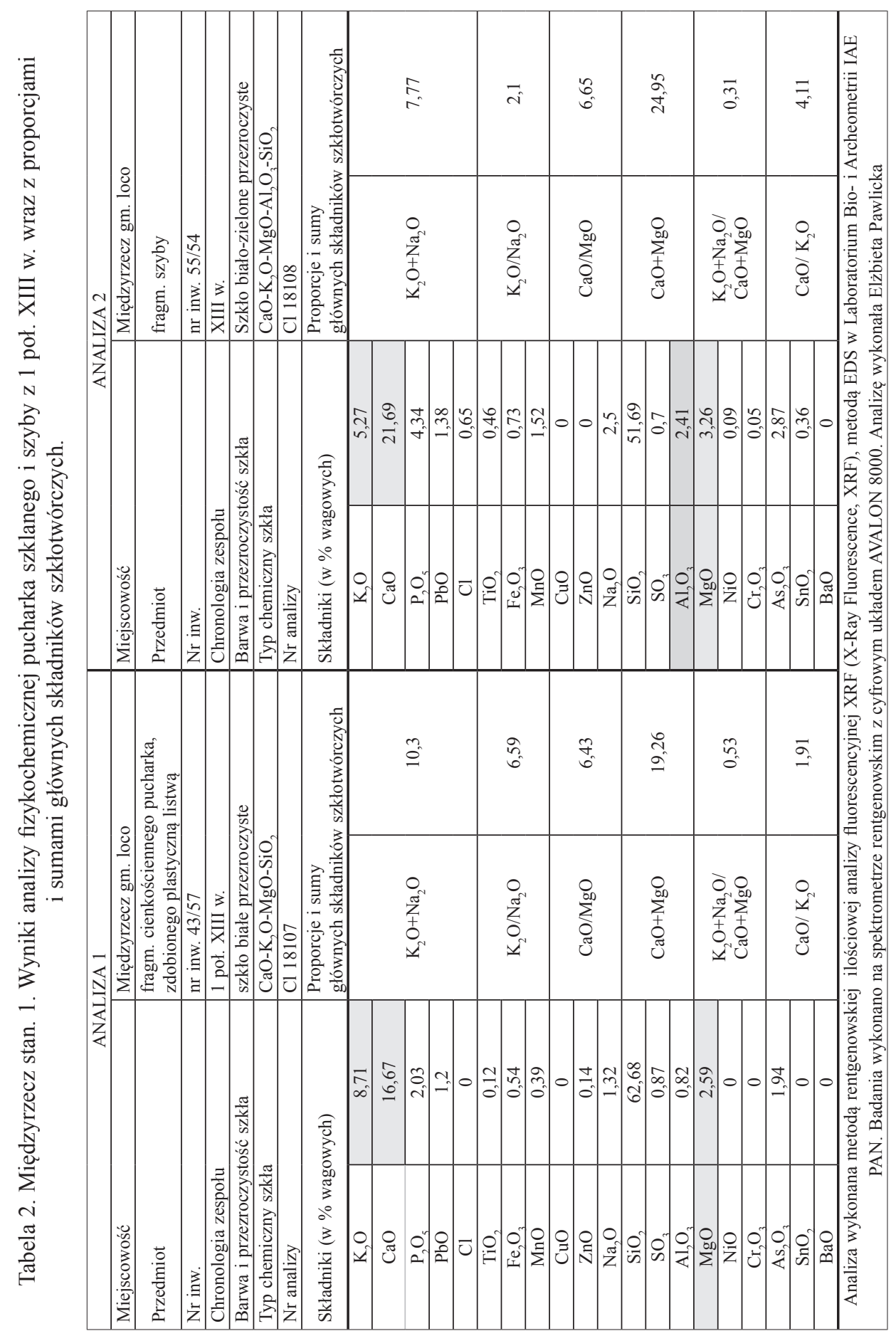


materiał z jedynej rozpoznanej późnośredniowiecznej huty w Sokołowie Budzyńskim wskazuje na produkcję szkła potasowego trzech odmian; żadna nie jest jednak zbliżona do odmiany, z której wykonano naczynie czy szybę z Międzyrzecza (Mucha 2017, s. 325-326).

\section{Zagadnienie pochodzenia}

Najwcześniejsze wzmianki o istnieniu średniowiecznych hut szkła w Wielkopolsce pochodzą z dokumentów biskupów poznańskich z początku XIV w. i dotyczą przypuszczalnej huty nad Cybiną pod Poznaniem. Zapis ten nie jest jednoznaczny, mówi jedynie o szklarzu (szklarzem w okresie późnośredniowiecznym i później nazywano również rzemieślnika szkliwiącego okna). Huty pod Olkuszem i Wolbromiem, wspomniane w dokumentach z połowy XIV w., mogły funkcjonować jeszcze wcześniej (Wyrobisz 1968, s. 16; 1987, s. 48). Podobnie jak w Małopolsce i Pomorzu Gdańskim, jedynym śladem po funkcjonujących już na początku XIV w. hutach są wzmianki w źródłach pisanych.

Jak dotąd, badania archeologiczne nie dostarczyły żadnych informacji o wczesnych hutach $\mathrm{z}$ tych regionów. Tylko niektóre $\mathrm{z}$ tych wspomnianych w historycznych zapisach huty objęto terenowymi badaniami weryfikacyjnymi, a nieliczne badaniami wykopaliskowymi. Były to jednak huty późniejsze (Mucha 1984; Rubnikowicz 1995; Wyrobisz 1987). Jednak ostatnie odkrycia podczas weryfikacyjnych badań powierzchniowych, pozwalają stwierdzić, że w Wielkopolsce już w 2. połowie XIV w. pracowała huta szkła produkująca szkło potasowe (Mucha 2017). Trudne jest ustalenie asortymentu tych hut. Zapewne produkowały w tym okresie przede wszystkim naczynia stołowe, raczej proste i niskiej jakości, rzadziej szyby. Znaczna w późnym średniowieczu unifikacja typów naczyń i ich składu chemicznego nie pozwala w sposób bardziej szczegółowy szukać miejsca ich produkcji; dotyczy to również szkieł nieco późniejszych (np. Milewska 2007, s. 6). Formy naczyń, ich zdobnictwo, mogą być w takich przypadkach punktem odniesienia do rozważań dotyczących pochodzenia. Podobnie bardzo słabo udokumentowany jest skład chemiczny produkowanego tam szkła. Przyjmuje się, że było to różnego rodzaju szkło potasowe - wytwarzane w tym okresie na terenie niemal całej środkowej i północnej Europy. Badania wykopaliskowe hut szkła w Wielkopolsce objęły huty późniejsze (XVII i XVIII-wieczne). Wcześniejsze huty z przełomu XIV i XV w. badane na Pomorzu Gdańskim zostały jedynie częściowo opublikowane (Rubnikowicz 1995). Z najwcześniejszym okresem ich działalności M. Rubnikowicz (1995, s. 61) wiąże dwa typy popularnych naczyń do picia - niskich szklanic-pucharków i wysokich szklanic fletowatych. Można stwierdzić, że asortyment wyrobów był ściśle związany z zapotrzebowaniem i koniunkturą gospodarczą regionu. Lepiej przedstawia się stan badań na Śląsku. Pierwsze informacje o lokalizacji hut dotyczą początku XIV wieku. Prężnie działające huty leśne mogły pracować już w koń- 
cu wieku XIII (Gluziński 1987, s. 63-64). Dobrym przykładem dystrybucji wyrobów szklanych są inwentarze ze śląskich zamków w Bardzie i Szczerbie, które pozostawały we władztwie czeskim w 2. połowie XIV i XV w. i naturalną koleją rzeczy zaopatrywały się w hutach czeskich (Francke 1994).

Nie można jednoznacznie określić pochodzenia naczyń odkrytych w Międzyrzeczu. W poziomach osadniczych grodu międzyrzeckiego z XIII do 1. połowy XIV w. znaleziono szereg pozostałości produkcji szklarskiej - warsztatu z rozpoznanym wytopem z surowców prymarnych. Była to pracownia typu A - niewielka, prawdopodobnie sezonowa huta, która krótko mogła działać już od 1. połowy XIII wieku. Produkowano w niej zapewne niskoalkaliczne szkło potasowo-wapniowe. Określenie asortymentu pracowni nie jest proste - jedną z głównych przyczyn jest zły stan zachowania gotowych wyrobów oraz - jak w innych wcześniejszych pracowniach szklarskich - brak półfabrykatów czy odpadów produkcyjnych. Można to tłumaczyć wtórnym wykorzystaniem cennego surowca. Najbardziej prawdopodobna jest produkcja prostych ozdób, prawdopodobnie obrączek-płacideł (Sawicka 2015). Ten najmłodszy warsztat szklarski w Międzyrzeczu Stanisław Kurnatowski łączy z handlowym przedsięwzięciem kasztelanii przy udziale rzemieślnika kontraktowego, co thumaczyłoby ulokowanie niewielkiej huty $\mathrm{w}$ grodzie, a nie $\mathrm{w}$ istniejącym już lokacyjnym mieście (Kurnatowski, Nalepa 1961, s. 141).

Skład chemiczny przebadanego fizykochemicznie fragmentu pucharka z 1. połowy XIII w., a więc $\mathrm{z}$ okresu, w którym pracowała huta, jest zbliżony do składu pozostałości produkcyjnych, ale absolutnie nie świadczy to o miejscowej produkcji naczyń. Poza miejscową, słabo udokumentowaną produkcją istniał dalekosiężny handel wyrobami bardziej luksusowymi. Niewykluczone, że osadzona w 2. połowie XIII w. w Międzyrzeczu kolonia mieszczan niemieckich (Kurnatowski 2015, s. 34 i tam dalsza literatura) była czynnikiem stymulującym kontakty handlowe $\mathrm{z}$ niemieckimi centrami produkcji szkła.

Od 1. ćwierci XIII w. zaczęły działalność manufaktury weneckie eksportujące swoje wyroby do południowej i środkowej Europy, w mniejszym stopniu na Śląsk, do miast hanzeatyckich czy Skandynawii. Szklana zastawa stołowa upowszechniła się na Śląsku od 2. połowy XIII w.; były to przede wszystkim pucharki sprowadzane z hut południowoniemieckich (Szajt 2015, s. 59). Od 2. połowy XIII w. zaczęły działalność huty czeskie najbliższe Wielkopolsce, jednak wyroby tych hut zaczęły konkurować z importowanymi luksusowymi naczyniami dopiero od wieku XV (Sedlačkova 2013, s. 239; Prokopová 2014, s. 140). Od wieku XIII działały leśne huty niemieckie przeżywające swój rozkwit w wieku XV (Steppuhn 2003, s. 9), a wcześniej stare nadreńskie i południowoeuropejskie centra wytwórcze. 


\section{PODSUMOWANIE}

Z przebadanych późnośredniowiecznych poziomów osadniczych na grodzie, obejmujących prawie półtora wieku pochodzi jedynie kilkanaście ułamków szyb i 530 drobnych fragmentów naczyń szklanych. Naczynia te pochodziły najpewniej z siedziby kasztelanii. Zarówno przekazy źródłowe, jak i wyniki badań archeologicznych świadczą, że w XIII i do połowy XIV w. szklane naczynia i szyby okienne były spotykane dość rzadko, na bardziej rozwiniętych obszarach dawnej Polski, a nawet na Pomorzu i Śląsku. Głównym odbiorcą był przede wszystkim bogaty patrycjat, kościoły i zamożne dwory.

W wypadku grodu międzyrzeckiego można przyjąć, że zamieszkiwały go grupy osób, których zamożność i pozycja społeczna pozwalała na nabywanie luksusowych, importowanych towarów, w tym wyrobów ze szkła.

Źródłem do porównań zabytków międzyrzeckich były zbiory naczyń szklanych pochodzące z badań wykopaliskowych w miastach hanzeatyckich na Pomorzu (Elbląg i Toruń) oraz z miast i zamków na Śląsku, które były naturalnym odbiorcą produktów hut czeskich. Można stwierdzić, że w tym samym czasie na tych obszarach znajdowano podobne typy naczyń. Było to spowodowane znaczną unifikacją wyrobów szklanych, która nastąpiła na przełomie XIII i XIV w., a dotyczyła zarówno form, jak i zdobień, docierały więc do Międzyrzecza naczynia ze środkowej i północnej Europy.

\section{LITERATURA}

Arndt B. 2008, Lifestyle. Nachweise für Luxus im spätmittelalterlichen Göttingen?, [in:] Lübecker Colloquium zur Stadtarchäologie im Hanseraum VI: Luxus und Lifestyle, ed. K. Kimminus-Schneider, D. Ehrenberg, M. Schneider, C. Sheehan, Beck, s. 169-184.

Banach B., Kurnatowski S., Urbańska-Łosińska A., Zamelska-Monczak K. 2015, Gród i zamek późnośredniowieczny, [w:] red. S. Kurnatowski, Międzyrzecz. Gród i zamek w wiekach IX-XIV, s. 217-264.

Baumgartner E. 1987, Glas des späten Mittelalters: Die Sammlung Karl Amendt, Dusseldorf.

Beutmann J. 2014, Glasfünde des späten Mittelalters aus Sachsen, [w:] red. E. Černa, P. Steppuhn, Glasarchäologie in Europa. Regionen - Produkte - Analysen, Most, s. 145-168

Biszkont J. 2005, Późnośredniowieczne szklarstwo na Ślasku, Wrocław.

Černa E., 1998, Sklo ve výbave středovékého mosteckého domu, „Archeologia Historica”, t. 22, s. 331-344.

Černa E., Frýda F. 2010, Sklo vrcholného středověku - současný stav a perspektivy studia historických technologií, „Archeologia Historica” 35, 1-2, s. 335-357.

Ciepiela S. 1971a, Zabytki szklane ze Świecia nad Wista, „Pomorania Antiqua”, t. 3, s. 479-496.

- 1971b, Ozdoby i naczynia szklane odkryte w Nakle nad Notecia, „Wiadomości Archeologiczne”, t. 36 , s. 203-212.

- 1971 c, Zabytki szklane z Solca nad Wista od końca XV do XVIII/XIX w., „Studia i Materiały z Historii Kultury Materialnej”, t. 45, s. 173-214.

- 1987, Wyroby szklane od połowy XIII do połowy XVII wieku, [w:] Polskie szkło do połowy XIX wie$k u$, s. 63-70, Wrocław-Warszawa-Kraków-Gdańsk-Łódź, s. 70-79.

- 1991, Szklanice fletowate ze Starego Miasta w Warszawie (XIV/XV - 1 ćwierci XVII wieku), Acta Universitatis Nicolai Copernici, seria Archeologia XIX, Archeologia szkła 5, s. 25-42.

Dekówna M. 1980, Szkło w Europie wczesnośredniowiecznej, Wrocław-Warszawa-Kraków-Gdańsk. 
Francke Cz. 1994, Późnośredniowieczne wyroby ze szkła z zamków w Bardzie i Gniewoszowie, woj. Watbrzych, „Silesia Antiqua”, t. 36-37, s. 95-112.

Frýda F. 1991, Typologie středovekékeho skla v Čechach od 13. do 15./16. stoleti, Acta Universitatis Nicolai Copernici, seria Archeologia XVIII, Archeologia szkła 9, s. 235-262.

Gasparetto A. 1975, La verrerie venitienne et ses relations avec le Lewant Balkanique au Moyen Age, in: Verre medieval aux Balkans ( $V^{b}-X V^{E}$ s.), V. Čubrilovič (ed.), Beograd.

Glaskultur... 2003, Glaskultur in Niedersachsen, [in:] Archäeologie und Bauforschung in Lüneburg, Bd. 5, ed. E. Ring, Husum.

Gluziński W. 1987, Szklarstwo ślaskie od połowy XIII do polowy XVII wieku, [w:] Polskie szkło do potowy XIX wieku, Wrocław-Warszawa-Kraków-Gdańsk-Łódź, s. 63-69.

Gołębiewski A. 1992, Ornamentyka późnośredniowiecznych i nowożytnych naczyń szklanych (analiza zabytków archeologicznych z Elblaga i Torunia), „Kwartalnik Historii Kultury Materialnej”, t. 40, s. 469-493.

- 1998, Użytkowanie naczyń szklanych w średniowiecznych miastach Pomorza i Prus, „Archeologia Historica Polona", t. 7, s. 213-229.

Haggrén G., Sedláčkova H. 2007, Ribbed beakers with applied glass threads in Europe, „Památky archeologické" 98 , s. 185-250.

Harden D.B. 1966, Some glass fragments, mainly of the 12th-13th century a.d. from Northern Apulia, „Journal of Glass Studies”, vol. 8, s. 70-79.

Historie... 2005, Historie sklářskè výroby v českých zemich, I. dil. Od počatkú do konce 19. stoletni, Praha.

Kraków... 2007, Kraków. Europejskie miasto prawa magdeburskiego 1257-1791. Katalog wystawy Kraków.

Kurnatowski S. 2015, Dzieje Międzyrzecza w świetle źródet pisanych, [w:] red. S. Kurnatowski, Międzyrzecz. Gród i zamek w wiekach IX-XIV, Warszawa, s. 19-42.

Kurnatowski S., Nalepa J. 1961, Z przeszłości Międzyrzecza, Poznań.

Markiewicz M. 1989, Szklanice fletowate z XIV/XV-XVIII wieku odkryte na zamku w Kole (woj. konińskie), Acta Universitatis Nicolai Copernici, seria Archeologia XIV, Archeologia szkła 3, s. 13-25.

Medieval glass... 2010, Medieval glass for Popes, Princes, and Peasants, ed. D. Whitehouse, Corning-New York.

Milewska M. 2007, Późnośredniowieczne i wczesnonowożytne importowane naczynia szklane z zamku w Pucku, „Kwartalnik Historii Kultury Materialnej” 55, s. 5-20.

Mucha M. 1984, Archeologiczna weryfikacja nowożytnych hut szkła na terenie Wielkopolski poludniowo-wschodniej, Acta Universitatis Nicolai Copernici, seria Archeologia 10, s. 123-142.

- 2000, Badania nad technologia wytopu szkła w hutach Wielkopolski wschodniej od XVII do polowy XIX wieku, „Archeologia Historica Polona”, t. 8, s. 247-280.

- 2017, Późnośredniowieczna huta szkła w Wielkopolsce. Sokołowo Budzyńskie, gm. Budzyń, stan. 28 , [w:] Ceramika i szkło w archeologii i konserwacji, S. Siemianowska, P. Rzeźnik, K. Chrzan, red., Wrocław, s. 307-330.

Nawrolska G. 2008, A Way of Life. Luxury in a Mediewal Town, [in:] Lübecker Colloquium zur Stadtarchäologie im Hanseraum VI: Luxus und Lifestyle, ed. K. Kimminus-Schneider, D. Ehrenberg, M. Schneider, C. Sheehan, Beck, s. 509-520.

Olczak J. 1960, Zagadnienie produkcji szklarskiej w Międzyrzeczu Wielkopolskim w świetle dotychczasowych badań archeologicznych, „Archeologia Polski”, t. 5, z. 1, s. 125-134.

- 1995, Nowe materialy do dziejów użytkowania szkta na ziemiach polskich (część 3), Acta Universitatis Nicolai Copernici, Archeologia XXVII, Archeologia szkła 8, s. 3-52.

- 1999, Zabytki szklane, [w:] Komorowo, stanowisko 12: osadnictwo nowożytne (XVII-XVIII w.), s. 83-97.

Olczak J., Jasiewiczowa E. 1963, Szklarstwo wczesnośredniowiecznego Wolina, Szczecin.

Prokopová A. 2014, Forschundstand zum mittelalterlichen Glas in Prag, [w:] red. E. Černa, P. Steppuhn, Glasarchäologie in Europa. Regionen - Produkte - Analysen, Most, s. 127-143.

Rademacher F. 1933, Die deutschen Gläser des Mittelalters, Berlin.

Röber R. 2008, Luxus im spätmittelalterlichen Konstanz: Die Aussage archäeoligischer, schriftlicher und baulicher Quellen, [in:] Lübecker Colloquium zur Stadtarchäologie im Hanseraum VI: Luxus 
und Lifestyle, ed. K. Kimminus-Schneider, D. Ehrenberg, M. Schneider, C. Sheehan, Beck, s. 419-446.

Rubnikowicz M. 1995, Badania nad późnośredniowiecznym i nowożytnym hutnictwem szkła na Pomorzu Gdańskim, Acta Universitatis Nicolai Copernici, Archeologia 22, Archeologia szkła 6, s. 63-75.

Sawicka J. 2015, Średniowieczne pracownie szklarskie w Międzyrzeczu, „Slavia Antiqua”, t. 56, s. $125-166$.

Schutte S. 1983, Glas in der mittelalterlicher Stadt, [w:] Aus dem Alltag der mittelalterlicher Stadt, Handbuch zur Sonderausstellung vom 5 Dezember 1982 bis 24. April 1983 im Brehmer Landesmuseum für Kunst- und Kulturgeschichte (Focke-Museum), s. 133-144.

Ščapova J.L. 1973, Zasady interpretacji analiz skladu szkła zabytkowego, „Archeologia Polski”, t. 18, z. 1 , s. 15-72.

Sedlačkova H. 2003, Typologie des Glases aus dem 13 und 14 Jahrhundert aus Brünn, Mähren, [in:] Auf gläsernen Spuren. Der Beitrag Mitteleuropas zur archäologisch-historischen Glasforschung, ed. S Felgenhauer-Schmiedt, A. Hibner, H. Knittler, Wien, s. 127-138.

- 2010, Vypovidaci hodnota archeologických nálezů skla na Moravé z obdobi ca 1200-1550, „Archeologia Historica", 35/1-2, s. 359-366.

- 2013, Abriss einer Typologie der Mittealterlicher Glasimporte aus Brno/Brünn, Mähren, Tschechische Republik, AIHV Annales du $16^{\circ}$ Congrès, s. 237-240.

Sedlačkova H., Rohanová D., Lesák B., Šimončičová-Koóšová P. 2014, Medieval Glass from Bratislava (ca 1200-1450) in the Context of Contemporaneous Glass Production and Trade Contacts, „Památky archeologické", 105, s. 215-264.

Siemianowska S., 2015, Późnośredniowieczny pucharek z pionowymi żeberkami w studni klasztoru bernardynów, [w:] Średniowieczna studnia klasztoru bernardynów z Jaworza. Badania interdyscyplinarne, A. Muła (red.), Jawor, s. 137-144.

- 2015a, Późnośredniowieczne i nowożytne szkło naczyniowe z badań wykopaliskowych na Ostrowie Tumskim we Wrockawiu prowadzonych w latach 1949-1961, 1963, „Silesia Antiqua”, t. 50, s. 203-286.

Stephan H.G., Wedepohl K.H., Hartmann G. 1997, Mittelalterliches Glas aus dem Reichskloster und der Stadtwüstung Corvey, „Germania” 75/2, s. 673-715.

Steppuhn P. 2003, Glas als Kulturgut, [w:] Glaskultur in Niedersachsen, Edgar Ring ed., s. 9-17.

- 2016, Mittelalterliche und frühneuzeitliche Glasfunde aus der Altstadt von Lübeck, Lübeck.

Stiaffini D. 1999, Il vetro nel medioevo. Tecniche, strutture, manufatti, Roma.

Szajt J. 2015, Naczynia stolowe mieszczaństwa w XIII-XVI w. Przyczynek do studiów nad kultura stotu późnośredniowiecznego Śląska, [w:] Różne oblicza średniowiecza. Z interdyscyplinarnych badań nad historia i kultura wieków średnich, E.J. Kowalczyk (red.), t. 1, Wrocław, s. 45-66.

Teofil Prezbiter 1998, Diversarum Artium Schedula, przekład z jęz. łac. i opracowanie S. Kobielus, Kraków.

Wedepohl K.H. 1998, Mittelalterliches Glas in Mitteleuropa: Zusammensetzung, Herstellung, Rohstoffe, Nachrichten der Akademie der Wissenschaften in Göttingen. II. Matematisch-Physikalische Klasse. Nr. 1, s. 13-26

- 2003, Die chemische Charakterisierung mittelalterlicher Gläser und der Handel mit ihren Rohstoffen, „Beiträge zur Mittelalterarchäologie in Österreich” 19, s. 211-218.

- 2010, The manufacture of medieval glass. Glassmaking in Europe between A.D. 500-1500, [in:] D. Whitehouse (ed.), Medieval glass for Popes, Princes, and Peasants, Corning-New York.

Wyrobisz A. 1968, Szkło w Polsce od XIV do XVII w., Wrocław-Warszawa-Kraków.

- 1987, Wytwórczość szklarska od połowy XIII do połowy XVII wieku [w:] Polskie szkło do polowy XIX wieku, s. 48-62, Wrocław-Warszawa-Kraków-Gdańsk-Łódź. 